\title{
The Characteristics of Foreign Portfolio Investment
}

\author{
Jaisik Gong $^{1^{*}}$ and Choong-hwan Kim ${ }^{2}$ \\ ${ }^{1}$ Dept. of Finance \& Insurance, Daegu University, Corresponding Author \\ ${ }^{2}$ Dept. of Industrial Information, Kongju Nat'l University \\ 외국인 포트폴리오 투자의 특징 \\ 공재식", 김충환 ${ }^{2}$ \\ ${ }^{1}$ 대구대학교 금융보험학과, ${ }^{2}$ 공주대학교 산업정보학과
}

\begin{abstract}
After the year of 2000, the Korean government has abolished the limit on foreign investments. Foreign investments in the domestic market have been thriving since. In domestic stock market, the proportion of market value held by foreign investors reaches over $40 \%$. There are many followers in the markets, asking about what kinds of the firm that foreign investors prefer. Prior researches show that foreign investors in the American and European markets prefer stocks of the firm which are well known and are geographically closer. In this paper, we attempt to define the financial characteristics of the firms in which foreigners invest in the Korean market. The result shows that foreign investors in the domestic market tend to prefer firms with high market value of capital and dividend yield. It also shows that foreign investors in the Korean market choose firms with high book value to market value over others, while the firms with high debt ratio and the portion of the largest stock holders are shunned. This research suggests that foreign portfolio investments in the Korean market have contributed to liquidity of stock market and changed the governance structure of domestic firms in a positive way.
\end{abstract}

요 약 우리나라는 2000년도부터 외국인투자 한도의 전면폐지로 외국인투자가 크게 증가하였다. 국내기업들의 소 유구조가 급격히 변모하면서 외국인투자자가 주식시장 시가총액에서 차지하는 비중을 보면 $40 \%$ 를 상회하고 있고, 외국인지분율이 $50 \%$ 를 넘는 기업들도 상당수 나타나고 있다. 국내투자자들 사이에서는 외국인투자자가 선호하는 국 내기업의 재무적 특성 또는 주식의 종류들에 대한 관심이 지대하다. 구미의 연구들에 따르면, 미국과 유럽시장에서 의 외국인투자자들은 잘 알려져 있거나 지리적으로 가까운 지역의 기업주식 또는 투명하고 유동성이 높은 주식을 선호한다고 알려져 있다. 본 연구는 국내시장에서 외국인투자자가 투자종목으로 선호하는 국내주식의 종류 또는 국 내기업의 재무적 특성을 분석하였다. 연구결과, 한국시장에서의 외국인투자자들은 자본의 시가총액이 큰 기업과 배 당수익률이 높은 기업을 매우 선호하는 것으로 나타났다. 한국시장에서 활동하는 외국인투자자들은 또한 장부가-시 장가 비율이 높은 가치주(value firms)를 보다 선호하고 있는 반면, 부채비율과 최대주주 1 인 지분비율이 높은 기업 에 대하여는 투자를 회피하고 있는 것으로 나타났다.

Key Words : Foreign Investment; Portfolio; Dividend

\section{Introduction and Prior Literature}

This research attempts to analyze financial characteristics of firms that foreign investors in the Korean market prefer. After the year of 2000, the Korean government has abolished the limit on foreign investments. Foreign

This research was supported by the Daegu University Research Grant, 2007.

"Corresponding Author : Jaisik Gong(jaigong@hanmail.net) 
investments in the domestic market have been thriving since. In domestic stock market, the proportion of market value held by foreign investors reaches over $40 \%$. There are many followers in the markets, asking about what kinds of the firm that foreign investors prefer. In the past researches, financial characteristics or stocks of the firms foreign investors prefer have been explored. They show that foreign investors in the American and European markets prefer stocks of the firm which are well known and are geographically closer.

Foreign investors' domestic portfolio disposition connects to home bias in international diversified investments. Their decision making should be understood in terms of information asymmetry between domestic and foreign investors. Foreign investors have tendency (home bias) to choose stocks they are more familiar with, such as ones from their home countries. Studies by Huberman [1], and Ivkovich and Weisbenner [2], claim that American investors usually prefer stocks of the firms which are geographically closer. Brennan and Cao [3], took this home bias phenomena to an international level and created a theory model that takes into account the information asymmetry between domestic and foreign investors, and discovered that domestic investors are better informed about the market. Corvig Lau, and $\mathrm{Ng}$ [4], found that investing in foreign funds depends on the domestic firm's export, exchange index stocks, and overseas listings, since foreign fund managers are relatively less informed than domestic fund managers. This, they claim, is attributable to information asymmetry between domestic and foreign investors. Kang and Stulz [5], found that foreign investors in Japan tend to focus on large companies and those with large exports, and concluded that foreign investors choose large companies in which sufficient enough information has been out to the market, to overcome adverse information asymmetry. Similar to former, Falkenstein [6] found that American mutual funds prefer stocks with high transparency and liquidity. Dahlquist and Robertson [7] studied firms in Switzerland to find characteristics of the firms which foreign investors prefer. They found that in Switzerland, foreign investors prefer large companies with low

[Table 1] Difference Analysis of Foreign Ownership by Financial Characteristics

\begin{tabular}{|c|c|c|c|c|c|c|c|c|}
\hline & \multicolumn{5}{|c|}{ Group Mean by Accountin Variable } & \multirow{2}{*}{$\begin{array}{c}\text { Mean } \\
\text { Overall } \\
\text { Average }\end{array}$} & & Obs \\
\hline & Q1 & Q2 & Q3 & $\mathrm{Q} 4$ & Q5 & & AverageDiff. & Obs No. \\
\hline MktCap(mil.) & 3,561 & 13,844 & 28,799 & 69,909 & $1,681,092$ & 359,857 & $<.0001$ & 3,176 \\
\hline Ratio & 1.51 & 2.17 & 3.42 & 5.65 & 20.17 & 6.59 & $<.0001$ & 3,176 \\
\hline Div_Yield & 0 & 0.0004 & 0.019 & 0.042 & 0.135 & 0.039 & $<.0001$ & 3,176 \\
\hline Ratio & 0.68 & 5.37 & 12.42 & 8.97 & 5.52 & 6.59 & $<.0001$ & 3,176 \\
\hline Risk & $2.7 \mathrm{E} \quad 7$ & $2.0 \mathrm{E} \quad 6$ & $8.9 \mathrm{E} \quad 6$ & 0.00004 & 0.052 & 0.010 & $<.0001$ & 3,176 \\
\hline Ratio & 13.92 & 8.33 & 5.47 & 3.52 & 1.17 & 6.59 & $<.0001$ & 3,176 \\
\hline BME & 0.130 & 0.373 & 0.700 & 1.326 & 13.042 & 3.117 & $<.0001$ & 3,176 \\
\hline Ratio & 16.83 & 7.27 & 4.04 & 3.21 & 1.63 & 6.59 & $<.0001$ & 3,176 \\
\hline Current & 0.54 & 0.92 & 1.25 & 1.70 & 3.54 & 1.59 & 0.951 & 3,176 \\
\hline Ratio & 6.49 & 6.27 & 6.39 & 6.45 & 7.34 & 6.59 & 0.951 & 3,176 \\
\hline Leverage & 3.20 & 0.62 & 1.03 & 1.67 & 13.20 & 2.67 & $<.0001$ & 3,176 \\
\hline Ratio & 7.73 & 8.12 & 7.93 & 6.12 & 3.06 & 6.59 & $<.0001$ & 3,176 \\
\hline Largest & 0.04 & 0.17 & 0.27 & 0.38 & 0.55 & 0.28 & 0.043 & 2,669 \\
\hline Ratio & 5.48 & 6.27 & 5.63 & 6.65 & 5.76 & 6.59 & 0.043 & 2,669 \\
\hline Cash_Holdings & 0.002 & 0.012 & 0.030 & 0.059 & 0.179 & 0.056 & 0.095 & 3,176 \\
\hline Ratio & 5.81 & 5.76 & 5.80 & 7.26 & 8.31 & 6.59 & 0.095 & 3,176 \\
\hline \multicolumn{9}{|c|}{$\begin{array}{l}\text { Ratio = Foreign ownership ratio (The portion of foreigners'ownership of total number of common stocks } \\
\text { outstanding), Foreign }=\log (\text { Ratio/(100 Ratio)),Largest }=\text { Ownership ratio of the largest shareholder, } \\
\text { MktCap = Total number of common stocks outstanding } \times \text { stock price at year end(=market capitalization } \\
\text { of common stocks)=(firm size), Ln_MktCap }=\log (\text { Mktcap),Div_Yield }=(\text { Cash dividend }+ \text { Stock dividend }) / \\
\text { Market capitalization of common stocks, Risk =Volatility of cash flows(Variance over the past } 5 \text { years of } \\
\text { EBIT and depreciation), BME =(book value of common stocks)/(market value of common stocks); (higher } \\
\text { BME=value firms, lowerBME=growth firms), Current =Current asset/ Current Liabilities, Leverage =Total } \\
\text { debt / Total capital, Cash_Holdings =Cash and cash equivalents /(Total asset - Cash and cash equivalent). }\end{array}$} \\
\hline
\end{tabular}


dividend, and large cash holdings. Also, they found that foreign investors prefer firms with large exposure and international reputations with overseas listings, while they shunned firms with controlling shareholders.

In this paper, we attempt to define the financial characteristics of the firms in which foreigners invest in the Korean market.

\section{Methodology and Test Hypothesis}

\subsection{Methodology}

The sample in this paper consists of all firms listed on the Korea Stock Exchange in the year from 1991 to 2004. Financial and stock data on the sample firms are collected. Specifically, in order to determine the characteristics of domestic firms which foreign investors prefer, this paper examines how cross sectional variations in financial characteristic variables affect the proportion of foreign ownership.

This paper estimates the following regression model for the yearly, industry, and whole samples. A foreign ownership variable scaled by $\log ($ Ratio/(100 Ratio $))$ as a dependent variable is used.

Foreign $=\beta_{0}+\beta_{1}$ Ln_MktCap $+\beta_{2}$ Div_Yield $+\beta_{3}$ Risk $+\beta_{4}$ BME $+\beta_{5}$ Current $+\beta_{6}$ Leverage $+\beta_{7}$ Largest $+\beta_{8}$ Cash_Holdings $+\beta_{99} 03$ Yearly_Dummies

\subsection{Test Hypothesis}

In this paper, the testable hypothesis predicts the followings. According to the studies by Huberman [1], Ivkovich and Weisbenner [2], and Brennan and Cao [3], we posit in the hypothesis 1 that foreign investors have

[Table 2] Regression Analysis of Foreign Ownership by Calendar Year

\begin{tabular}{|c|c|c|c|c|c|c|c|c|}
\hline & 1998 & 1999 & 2000 & 2001 & 2002 & 2003 & 2004 & $\begin{array}{r}\text { Total } \\
\left(\begin{array}{ll}98 & 03\end{array}\right)\end{array}$ \\
\hline Ln_MktCap & $\begin{array}{c}2.03 \\
(12.42)^{\text {** }}\end{array}$ & $\begin{array}{c}1.72 \\
(12.02)^{* *}\end{array}$ & $\begin{array}{c}1.94 \\
(12.76)^{* *}\end{array}$ & $\begin{array}{c}1.99 \\
(14.55)^{* *}\end{array}$ & $\begin{array}{c}1.88 \\
(12.83)^{* *}\end{array}$ & $\begin{array}{c}1.93 \\
(12.46)^{* *}\end{array}$ & $\begin{array}{c}2.08 \\
(14.87)^{* *}\end{array}$ & $\begin{array}{c}1.89 \\
(32.90)^{* *}\end{array}$ \\
\hline Div_Yield & $\begin{array}{l}22.06 \\
(6.69)^{* *}\end{array}$ & $\begin{array}{c}12.94 \\
(2.69)^{* *}\end{array}$ & $\begin{array}{c}7.28 \\
(2.29)^{*}\end{array}$ & $\begin{array}{c}14.51 \\
(4.97)^{* *}\end{array}$ & $\begin{array}{c}7.72 \\
(2.04)^{*}\end{array}$ & $\begin{array}{c}9.36 \\
(1.33)\end{array}$ & $\begin{array}{l}20.44 \\
(3.69)^{* *}\end{array}$ & $\begin{array}{c}11.68 \\
(6.84)^{* *}\end{array}$ \\
\hline Risk & $\begin{array}{r}175.1 \\
(\quad 0.22)\end{array}$ & $\begin{array}{l}3.00 \\
(\quad 0.13)\end{array}$ & $\begin{array}{c}4.94 \\
(\quad 0.80)\end{array}$ & $\begin{array}{c}4.29 \\
(\quad 0.54)\end{array}$ & $\begin{array}{l}3.86 \\
(\quad 0.39)\end{array}$ & $\begin{array}{l}1.09 \\
(\quad 0.03)\end{array}$ & $\begin{array}{c}0.23 \\
(0.17)\end{array}$ & $\begin{array}{c}1.02 \\
(\quad 0.41)\end{array}$ \\
\hline BME & $\begin{array}{c}0.04 \\
(2.19)^{*}\end{array}$ & $\begin{array}{c}0.11 \\
(3.85)^{* *}\end{array}$ & $\begin{array}{c}0.05 \\
(3.11)^{* *}\end{array}$ & $\begin{array}{c}0.07 \\
(2.51)^{*}\end{array}$ & $\begin{array}{c}0.03 \\
(0.56)\end{array}$ & $\begin{array}{c}0.08 \\
(0.75)\end{array}$ & $\begin{array}{c}0.23 \\
(\quad 1.31)\end{array}$ & $\begin{array}{c}0.05 \\
(5.11)^{* *}\end{array}$ \\
\hline Current & $\begin{array}{c}0.27 \\
(1.06)\end{array}$ & $\begin{array}{c}0.55 \\
(2.15)\end{array}$ & $\begin{array}{c}0.33 \\
(\quad 1.10)\end{array}$ & $\begin{array}{c}0.12 \\
(0.64)\end{array}$ & $\begin{array}{c}0.10 \\
(0.43)\end{array}$ & $\begin{array}{l}0.08 \\
(\quad 0.39)\end{array}$ & $\begin{array}{c}0.29 \\
(1.72)\end{array}$ & $\begin{array}{c}0.11 \\
(1.19)\end{array}$ \\
\hline Leverage & $\begin{array}{c}0.01 \\
(1.05)\end{array}$ & $\begin{array}{r}0.006 \\
(\quad 1.64)\end{array}$ & $\begin{array}{l}0.006 \\
(0.48)\end{array}$ & $\begin{array}{r}0.009 \\
(\quad 0.34)\end{array}$ & $\begin{array}{c}0.02 \\
(\quad 0.94)\end{array}$ & $\begin{array}{c}0.08 \\
(\quad 0.53)\end{array}$ & $\begin{array}{l}0.03 \\
(\quad 0.26)\end{array}$ & $\begin{array}{l}0.005 \\
(2.21)^{*}\end{array}$ \\
\hline Largest & $\begin{array}{c}0.89 \\
(0.54)\end{array}$ & $\begin{array}{c}3.04 \\
(\quad 1.74)\end{array}$ & $\begin{array}{c}2.93 \\
(2.06)^{*}\end{array}$ & $\begin{array}{l}2.73 \\
(\quad 2.15)\end{array}$ & $\begin{array}{l}1.70 \\
\left(\begin{array}{l}1.41)\end{array}\right)\end{array}$ & $\begin{array}{c}1.93 \\
\left(\begin{array}{l}1.62)\end{array}\right.\end{array}$ & . & $\begin{array}{c}1.98 \\
(3.59)^{* *}\end{array}$ \\
\hline Cash_Holdings & $\begin{array}{c}3.38 \\
(1.29)\end{array}$ & $\begin{array}{c}3.96 \\
(\quad 0.79)\end{array}$ & $\begin{array}{c}2.50 \\
(0.40)\end{array}$ & 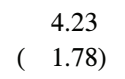 & $\begin{array}{l}1.30 \\
(\quad 0.36)\end{array}$ & $\begin{array}{c}6.78 \\
(1.88)\end{array}$ & $\begin{array}{c}3.52 \\
(1.32)\end{array}$ & $\begin{array}{c}0.92 \\
(0.66)\end{array}$ \\
\hline Const. & $\begin{array}{r}44.44 \\
(\quad 15.1)\end{array}$ & $\begin{array}{c}37.68 \\
(\quad 12.99)\end{array}$ & $\begin{array}{c}40.04 \\
(\quad 13.55)\end{array}$ & $\begin{array}{c}41.79 \\
(\quad 16.07)\end{array}$ & $\begin{array}{c}39.71 \\
(\quad 13.86)\end{array}$ & $\begin{array}{c}40.51 \\
(\quad 12.77)\end{array}$ & $\begin{array}{r}44.60 \\
(\quad 16.11)\end{array}$ & $\begin{array}{c}40.28 \\
(\quad 36.23)\end{array}$ \\
\hline $\mathrm{R}^{2}$ & 0.33 & 0.27 & 0.32 & 0.36 & 0.30 & 0.33 & 0.39 & 0.30 \\
\hline $\mathrm{F}$ & 26.58 & 21.27 & 28.53 & 32.67 & 25.55 & 27.56 & 44.34 & 155.01 \\
\hline $\mathrm{N}$ & 398 & 404 & 427 & 451 & 484 & 505 & 507 & 2.669 \\
\hline
\end{tabular}

Ratio $=$ Foreign ownership ratio (The portion of foreigners'ownership of total number of common stocks outstanding $)$, Foreign $=\log ($ Ratio/(100 Ratio) $)$,Largest $=$ Ownership ratio of the largest shareholder, MktCap $=$ Total number of common stocks outstanding $\times$ stock price at year end $(=$ market capitalization of common stocks) $=($ firm size $)$, Ln_MktCap $=\log$ (Mktcap),Div_Yield $=($ Cash dividend + Stock dividend )/ Market capitalization of common stocks, Risk =Volatility of cash flows(Variance over the past 5 years of EBIT and depreciation), BME =(book value of common stocks)/(market value of common stocks); (higher $\mathrm{BME}=$ value firms, lowerBME=growth firms), Current =Current asset/ Current Liabilities, Leverage $=$ Total debt $/$ Total capital, Cash_Holdings =Cash and cash equivalents /(Total asset - Cash and cash equivalent). 
tendency to choose stocks they are familiar with, by taking into account the information asymmetry. Since the studies by Falkenstein [6] and Dahlquist and Robertson [7] show that foreign investors avoid firms with controlling shareholders as well as high risk exposure, we posit in the hypotheses 1 and 2 that foreign investors prefer stocks of the firms with low financial risk and diversified ownership structure. Most Korean chaebul (business group) have controlling shareholders and the test of hypothesis 3 seems to be very interesting.

(Hypothesis 1): Foreign investors choose familiar and recognized companies in which sufficient enough information has been out to the market.

(Hypothesis 2): Foreign investors prefer stocks of the firms which have low risks such as in financial distress risks.

[Table 3] Regression Analysis of Foreign Ownership by Industry

\begin{tabular}{|c|c|c|c|c|c|c|c|}
\hline & Manuf. & $\begin{array}{c}\text { Ele. } \\
\text { Gas } \\
\text { Water }\end{array}$ & Constr. & Sale & Trans. & Comm. & Others \\
\hline Ln_MktCap & $\begin{array}{c}1.86 \\
(27.62)^{* *}\end{array}$ & $\begin{array}{c}0.24 \\
(1.10)\end{array}$ & $\begin{array}{c}2.43 \\
(7.11)^{* *}\end{array}$ & $\begin{array}{c}1.95 \\
(7.79)^{* *}\end{array}$ & $\begin{array}{c}2.78 \\
(7.26)^{* *}\end{array}$ & $\begin{array}{c}1.85 \\
(1.80)\end{array}$ & $\begin{array}{c}1.98 \\
(5.49)^{* *}\end{array}$ \\
\hline Div_Yield & $\begin{array}{c}10.82 \\
(5.87)^{\text {** }}\end{array}$ & $\begin{array}{c}7.14 \\
(0.26)\end{array}$ & $\begin{array}{c}1.59 \\
(\quad 0.17)\end{array}$ & $\begin{array}{l}17.75 \\
(1.56)\end{array}$ & $\begin{array}{c}32.25 \\
(6.18)^{* *}\end{array}$ & $\begin{array}{l}57.82 \\
(0.72)\end{array}$ & $\begin{array}{c}0.63 \\
(0.11)\end{array}$ \\
\hline Risk & $\begin{array}{c}6.00 \\
(\quad 0.76)\end{array}$ & $\begin{array}{r}110609 \\
(\quad 1.71)\end{array}$ & $\begin{array}{r}79.57 \\
(\quad 1.47)\end{array}$ & $\begin{array}{r}60.82 \\
(\quad 1.39)\end{array}$ & $\begin{array}{c}1736 \\
(\quad 0.64)\end{array}$ & $\begin{array}{c}5431249 \\
(0.87)\end{array}$ & $\begin{array}{c}0.92 \\
(\quad 0.18)\end{array}$ \\
\hline $\mathrm{BME}$ & $\begin{array}{c}0.05 \\
(3.96)^{* *}\end{array}$ & $\begin{array}{l}5.66 \\
(\quad 0.72)\end{array}$ & $\begin{array}{c}0.06 \\
(0.62)\end{array}$ & $\begin{array}{c}0.05 \\
(2.13)^{*}\end{array}$ & $\begin{array}{c}0.31 \\
(2.41)^{*}\end{array}$ & $\begin{array}{r}1.07 \\
(0.20)\end{array}$ & $\begin{array}{c}0.09 \\
(2.79) * *\end{array}$ \\
\hline Current & $\begin{array}{c}0.04 \\
(0.47)\end{array}$ & $\begin{array}{c}0.48 \\
(0.16)\end{array}$ & $\begin{array}{c}0.64 \\
(\quad 0.49)\end{array}$ & $\begin{array}{c}0.22 \\
(0.47)\end{array}$ & $\begin{array}{c}2.21 \\
(1.79)\end{array}$ & $\begin{array}{c}3.65 \\
(\quad 0.72)\end{array}$ & $\begin{array}{c}0.67 \\
(0.73)\end{array}$ \\
\hline Leverage & $\begin{array}{c}0.006 \\
(2.26)^{*}\end{array}$ & $\begin{array}{l}0.38 \\
(\quad 0.36)\end{array}$ & $\begin{array}{l}0.007 \\
(0.26)\end{array}$ & $\begin{array}{c}0.03 \\
(0.65)\end{array}$ & $\begin{array}{c}0.01 \\
(0.95)\end{array}$ & $\begin{array}{c}2.08 \\
(1.11)\end{array}$ & $\begin{array}{c}0.35 \\
(1.13)\end{array}$ \\
\hline Largest & $\left(\begin{array}{c}1.66 \\
(2.62)^{* *}\end{array}\right.$ & $\begin{array}{c}1.11 \\
(\quad 0.48)\end{array}$ & $\begin{array}{c}0.62 \\
(0.26)\end{array}$ & $\begin{array}{c}6.97 \\
(3.62)^{* *}\end{array}$ & $\begin{array}{l}0.07 \\
(\quad 0.02)\end{array}$ & $\begin{array}{c}0.59 \\
(0.14)\end{array}$ & $\begin{array}{c}5.21 \\
(0.79)\end{array}$ \\
\hline Cash_Holdings & $\begin{array}{c}2.60 \\
(1.61)\end{array}$ & $\begin{array}{c}0.80 \\
(0.07)\end{array}$ & $\begin{array}{c}2.02 \\
(\quad 0.83)\end{array}$ & $\begin{array}{c}0.94 \\
(0.17)\end{array}$ & $\begin{array}{c}7.31 \\
(0.41)\end{array}$ & $\begin{array}{l}25.42 \\
(0.69)\end{array}$ & $\begin{array}{r}12.99 \\
(\quad 1.03)\end{array}$ \\
\hline Year99 & $\begin{array}{c}0.31 \\
(0.66)\end{array}$ & $\begin{array}{l}0.07 \\
(\quad 0.09)\end{array}$ & $\begin{array}{c}2.23 \\
(1.77)\end{array}$ & $\begin{array}{c}0.32 \\
(0.23)\end{array}$ & $\begin{array}{c}1.90 \\
(0.70)\end{array}$ & & $\begin{array}{c}0.86 \\
(0.29)\end{array}$ \\
\hline Year00 & $\begin{array}{c}0.24 \\
(0.54)\end{array}$ & $\begin{array}{l}0.04 \\
(\quad 0.06)\end{array}$ & $\begin{array}{c}2.67 \\
(1.93)\end{array}$ & $\begin{array}{l}0.90 \\
(\quad 0.66)\end{array}$ & $\begin{array}{c}1.83 \\
(1.71)\end{array}$ & & $\begin{array}{c}0.47 \\
(\quad 0.14)\end{array}$ \\
\hline Year01 & $\begin{array}{c}0.19 \\
(0.45)\end{array}$ & $\begin{array}{l}0.004 \\
(\quad 0.003)\end{array}$ & $\begin{array}{c}0.24 \\
(\quad 0.19)\end{array}$ & $\begin{array}{c}0.005 \\
(0.004)\end{array}$ & $\begin{array}{c}0.95 \\
(0.38)\end{array}$ & & $\begin{array}{c}0.16 \\
(0.05)\end{array}$ \\
\hline Year02 & $\begin{array}{c}0.48 \\
(1.14)\end{array}$ & $\begin{array}{l}0.09 \\
(\quad 0.09)\end{array}$ & $\begin{array}{l}1.33 \\
(0.94)\end{array}$ & $\begin{array}{l}0.96 \\
(\quad 0.74)\end{array}$ & $\begin{array}{c}0.79 \\
(0.30)\end{array}$ & & $\begin{array}{c}0.11 \\
(0.04)\end{array}$ \\
\hline Year03 & $\begin{array}{c}0.50 \\
(1.19)\end{array}$ & $\begin{array}{l}0.59 \\
(\quad 0.60)\end{array}$ & $\begin{array}{c}2.18 \\
(1.69)\end{array}$ & $\begin{array}{l}0.41 \\
(\quad 0.32)\end{array}$ & $\begin{array}{c}2.71 \\
(0.98)\end{array}$ & & $\begin{array}{r}0.92 \\
(\quad 0.31)\end{array}$ \\
\hline Const. & $\begin{array}{l}39.88 \\
(\quad 31.04)\end{array}$ & $\begin{array}{l}5.18 \\
(\quad 0.83)\end{array}$ & $\begin{array}{r}50.56 \\
(\quad 7.28)\end{array}$ & $\begin{array}{r}40.48 \\
(\quad 8.13)\end{array}$ & $\begin{array}{l}61.64 \\
(\quad 10.73)\end{array}$ & $\begin{array}{r}45.85 \\
(\quad 1.75)\end{array}$ & $\begin{array}{r}41.45 \\
(\quad 5.55)\end{array}$ \\
\hline $\mathrm{R}^{2}$ & 0.29 & 0.35 & 0.44 & 0.40 & 0.60 & 0.59 & 0.66 \\
\hline $\mathrm{F}$ & 71.20 & 11.52 & 15.47 & 11.13 & 16.59 & 5.08 & 6.53 \\
\hline $\mathrm{N}$ & $\begin{array}{c}2,065 \\
(77.3 \%)\end{array}$ & $\begin{array}{c}27 \\
(1.0 \%)\end{array}$ & $\begin{array}{c}191 \\
(7.1 \%)\end{array}$ & $\begin{array}{c}205 \\
(7.6 \%)\end{array}$ & $\begin{array}{c}93 \\
(3.4 \%)\end{array}$ & $\begin{array}{c}11 \\
(0.4 \%)\end{array}$ & $\begin{array}{c}45 \\
(1.6 \%)\end{array}$ \\
\hline
\end{tabular}

Ratio $=$ Foreign ownership ratio (The portion of foreigners'ownership of total number of common stocks outstanding), Foreign $=\log ($ Ratio/(100 Ratio) $)$, Largest $=$ Ownership ratio of the largest shareholder, $\mathrm{MktCap}=$ Total number of common stocks outstanding $\times$ stock price at year end (=market capitalization of common stocks)=(firm size $),$ Ln_MktCap $=\log ($ Mktcap),Div_Yield $=($ Cash dividend + Stock dividend )/ Market capitalization of common stocks, Risk =Volatility of cash flows(Variance over the past 5 years of EBIT and depreciation), BME $=($ book value of common stocks)/(market value of common stocks); (higher BME=value firms, lowerBME=growth firms), Current $=$ Current asset $/$ Current Liabilities, Leverage =Total debt $/$ Total capital, Cash_Holdings =Cash and cash equivalents /(Total asset - Cash and cash equivalent). 
(Hypothesis 3): Foreign investors shun stocks of the firms with controlling shareholders.

\section{The Results}

Table 1 shows difference analysis in foreign ownership by accounting variable. In order to decide whether the level of foreign investment differs in relation to accounting variables such as firm size, risk, and leverage ratio and so on, the sample firms were divided in fifth, depending on the size of accounting variables. Wilcoxon $\mathrm{Z}$ test difference analysis has been applied on small samples of Q1 (groups with the smallest accounting variables) and Q5(groups with the largest accounting variables), as well as the average ratio of foreign ownership. The Wilcoxon test evaluates differences between paired or matched values, and the test focuses on whether the means or averages of the variables in matched samples differs significantly. Through this Wilcoxon test, we are able to confirm which accounting variable increases or decreases as foreigners increase their portfolio investments in domestic stocks. In Table 1, the Wilcoxon test shows that as the price of common stocks rise, foreign ownership follows the same pattern as well. The same pattern also followed when dividend yield changes. However, the risk variable of cash flow volatility rises, foreign ownership decreased in return.

Table 2 shows the result of regression analysis of foreign ownership and accounting variables, by calendar year. Those in which fixed effects such as industry effect are not controlled, but it reports that market value of common stocks (Ln_MktCap), didvidend yield

(Div_Yield), and book to market ratio of common stocks (BME) displays a very positive significant relationship with foreign ownership.

In Table 3, a regression analysis has been done with year dummies. In order to restrict industry effect, variables has been grouped by industry. Industries with restrictions or industrial uniqueness such as electricity, gas, waterworks, and communications, do not show a significant relationship with foreign ownership. However, in the manufacturing sector, as corporate decision making is made autonomously and takes the portion of $77.3 \%$ of the whole industry, the market value of common stocks (Ln_MktCp), dividend yield (Div_Yield), book to market value ratio of common stocks (BME), and ownership ratio of the largest share holders (Largest), explained significantly foreign ownership variable (Foreign). It seems that the reason foreign investors prefer large firms is because large companies are superior in terms of firm recognition, and liquidity. This theory runs parallel with Huberman [1], who claimed in a situation of information asymmetry, investors tend to invest on firms they are familiar with, and also firms with largest cachet of information. Also, it is found that foreign investors prefer stocks high dividend yield and high BME ratio, meaning they prefer value stocks. This result is in contrast to that of Dahlquist and Robertsson [7], in which foreign investors in Swiss market preferred growth stocks. On the contrary, foreign investors shun away from firms with high debt ratio and controlling shareholders. This also fits in with the research conducted by Leus, Lins, and Warnock [8].

\section{Conclusions}

This research defines financial characteristics of firms with large proportion of foreign ownership.

The result shows that foreign investors prefer firms with large market value of capital, and high dividend yield. Also, they choose value firms with high book to market value ratio, while shunning away from firms with high debt ratio and high ownership ratio of the largest shareholders.

This research suggests that foreign investors, who grew large in number after the year of 2000 , are evaluated to have contributed to liquidity of stock market and changed the governance structure of domestic firms. Foreign investors also kept the management transparent, by serving as a brake on the management if it gets out of hand. Moreover, foreign portfolio investments strengthened international competitiveness of domestic firms by reducing capital cost, and therefore, contributing to the development of domestic capital market and national economy. 


\section{References}

[1] Huberman, G., "Familiarity breeds investment", Review of Financial Studies 14, pp. 659-680, 2001.

[2] Ivkovic, Z. and S. Weisbenner, "Local Does as Local Is: Information Content of The Geography of Individual investors' Common Stock Investments", Journal of Finance LX(1), pp. 267-306, 2005.

[3] Brennan, Michael J. and H. Henry Cao, "International Portfolio Investment Flows", Journal of Finance LII(5), pp. 1851-1880, 1997.

[4] Covrig, V., S. Lau, and L. Ng, "Do domestic and foreign fund managers have similar preferences for stock characteristics? A cross-country analysis", Journal of International Business Studies 37, pp. 407-429, 2006.

[5] Kang, J-K., Stulz, R.M., "Why is there a home bias? an analysis of foreign portfolio equity ownership in Japan”, Journal of Financial Economics 46, pp. 3-28, 1997.

[6] Falkenstein, E.G., "Preferences for stock characteristics as revealed by mutual fund portfolio holdings", Journal of Finance 51, pp.111-135, 1996.

[7] Dahlquist M., and and C. Robertsson, "Direct foreign ownership, institutional investors, and firm characteristics", Journal of Financial Economics 59, pp. 413-440, 2001.

[8] Leuz, C., K. Lins, and F. Warnock, "Do foreigners invest less in poorly governed firms?", Working paper, University of Pennsylvania, 2005.

\section{Jaisik Gong}

[Regular member]

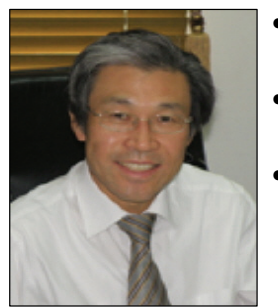

- Aug. 1984 : Seoul National Univ., MBA

- Aug. 1992 : Louisiana State Univ.(U.S.), Ph.D.

- Mar. $1995 \sim$ current : Daegu University, Dept. of Finance \& Insurance, Professor

\section{Choong-hwan Kim}

[Regular member]

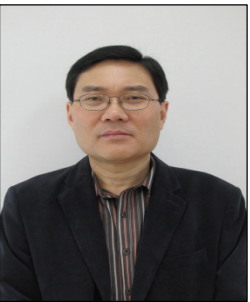

- Feb. 1983 : Sungkyunkwan Univ., BA

- Dec. 1995 : The Univ. of Texas at Austin (U.S.), Ph.D.

- Mar. $1996 \sim$ current : Kongju Nat'1 University, Dept. of Industrial Information, Professor

$<$ Research Interests $>$

Central Bank, Macroeconomics, Banking

$<$ Research Interests $>$

Corporate Finance, Banking 